JURNAL ILMIAH MANAJEMEN BISNIS DAN INOVASI UNIVERSITAS SAM RATULANGI

\title{
ANALISIS PENGARUH BUDAYA ORGANISASI, KOMUNIKASI, PENDIDIKAN DAN PELATIHAN TERHADAP KINERJA PEGAWAI SEKRETARIAT DAERAH KABUPATEN MINAHASA TENGGARA
}

\author{
Armando A. Kotangon, Bernhard Tewal, Greis M. Sendow \\ Universitas Sam Ratulangi \\ A R T I C L E I N F O
}

Keywords: Organizational Culture,
Communication, Education and
Training, Performance.

Kata Kunci : Budaya Organisasi, Komunikasi, Pendidikan dan Pelatihan, Kinerja Pegawai

Corresponding author:

\section{Armando A. Kotangon}

armandokotangon@gmail.com
Abstract: Performance plays an important role in determining the success of a company or organization. Performance is the work result in quality and quantity achieved by an employee in carrying out his duties according to the responsibilities assigned to him. High or good employee performance can be used as one of the basic factors to measure the success of an organization in achieving its goals. This study aims to determine the simultaneous and partial influence of organizational culture, communication, education and training on employee performance, the partial influence of organizational culture on employee performance, the partial influence of communication on employee performance, the partial influence of education and training on employee performance of the District Secretariat. Southeast Minahasa. Respondents in this study amounted to 73 employees who are civil servants. This study uses multiple linear regression analysis. The results of this study simultaneously variable Organizational Culture, Communication, Education and Training together have a significant effect on Employee Performance, then partially the Organizational Culture variable has a positive and insignificant effect on the Performance variable, partially the Communication variable has a positive and insignificant effect on the variable Performance, partially the Education and Training variable has a positive and significant effect on the performance variable.

Abstrak: Penelitian ini bertujuan mengetahui pengaruh secara simultan dan parsial budaya organisasi, komunikasi, pendidikan dan pelatihan terhadap kinerja pegawai, pengaruh secara parsial budaya organisasi terhadap kinerja pegawai, pengaruh secara parsial komunikasi terhadap kinerja pegawai, pengaruh secara parsial pendidikan dan pelatihan terhadap kinerja pegawai Sekretariat Daerah Kabupaten Minahasa Tenggara. Responden dalam penelitian ini berjumlah 73 pegawai yang berstatus pegawai negeri sipil. Penelitian ini menggunakan analisis regresi linier berganda. Hasil Penelitian ini secara simultan variabel Budaya Organisasi, Komunikasi, Pendidikan dan Pelatihan secara bersama-sama berpengaruh signifikan terhadap Kinerja Pegawai, kemudian secara parsial variabel Budaya Organisasi berpengaruh positif dan tidak signifikan terhadap variabel Kinerja, secara parsial variabel Komunikasi berpengaruh positif dan tidak signifikan terhadap variabel Kinerja, secara parsial variabel Pendidikan dan Pelatihan berpengaruh positif dan signifikan terhadap variabel Kinerja. 


\section{LATAR BELAKANG}

Kinerja berperan penting dalam menentukan keberhasilan suatu perusahaan atau organisasi. Kinerja adalah hasil kerja secara kualitas dan kuantitas yang dicapai oleh seorang pegawai dalam melaksanakan tugasnya sesuai tanggung jawab yang diberikan kepadanya. Kinerja pegawai yang tinggi atau baik dapat dijadikan salah satu faktor dasar tolak ukur keberhasilan suatu organisasi dalam mencapai tujuannya (Mangkunegara, 2013:67).

Sesuai dengan konteks pemberdayaan sumber daya manusia, agar menghasilkan pegawai yang profesional diperlukan adanya acuan baku yang diberlakukan oleh suatu organisasi. Acuan tersebut adalah budaya organisasi yang secara sistematis menuntun pegawai untuk meningkatkan kinerjanya. Budaya organisasi sering disebut juga budaya kerja karena tidak bisa dipisahkan dengan kinerja (performance) sumber daya manusia. Semakin kuat budaya organisasi, semakin kuat pula dorongan kerja. Salah satu faktor yang membedakan suatu organisasi dari organisasi yang lainnya ialah budayanya.

Faktor lain yang mempengaruhi kinerja pegawai adalah komunikasi. Komunikasi dalam suatu organisasi merupakan aktivitas yang selalu hadir, conditio sinne quanon, karena komunikasi adalah sarana yang digunakan para pegawai, baik secara formal maupun informal, untuk berdiskusi, bertukar pikiran, membuat laporan kepada atasan, memberikan arahan kepada bawahan dan sebagainya. Menurut Ardana dkk. (2012:138) komunikasi merupakan kunci pembuka terjadinya hubungan kerja sama antara pimpinan dengan karyawan dan antar karyawan. Sumber daya manusia yang merupakan salah satu faktor pendukung keberhasilan juga tidak bisa optimal jika sumber daya tersebut tidak memiliki pengetahuan dan kemampuan yang memadai, hal itu berpengaruh terhadap kinerja pegawai di organisasi. Dengan demikian perlu adanya Pendidikan dan pelatihan untuk mendukung kinerja sumber daya manusia tersebut supaya kinerja pegawai menjadi baik seperti yang diharapkan pegawai, dengan demikian bisa menjadi faktor pendukung yang optimal dalam mencapai tujuan organisasi.

Berdasarkan latar belakang tersebut, maka pertanyaan penelitian (Research Questions) adalah (1) Bagaimana pengaruh Budaya Organisasi, Komunikasi, Pendidikan dan Pelatihan terhadap Kinerja Pegawai Sekretariat Daerah Kabupaten Minahasa Tenggara?, (2) Bagaimana pengaruh Budaya Organisasi terhadap Kinerja Pegawai Sekretariat Daerah Kabupaten Minahasa Tenggara?, (3) Bagaimana pengaruh Komunikasi terhadap Kinerja Pegawai Sekretariat Daerah Kabupaten Minahasa Tenggara?, (4) Bagaimana pengaruh Pendidikan dan Pelatihan terhadap Kinerja Pegawai Sekretariat Daerah Kabupaten Minahasa Tenggara?

\section{Budaya Organisasi}

\section{LANDASAN TEORI}

Robbins (2001:523-524) menggambarkan bagaimana budaya suatu organisasi dibangun dan dipertahankan. Budaya asli ditunjukkan dari filsafat pendirinya. Selanjutnya budaya ini sangat mempengaruhi kriteria yang digunakan dalam mempekerjakan karyawannya. Tindakan dari manajemen puncak menentukan iklim umum dari perilaku baik yang dapat diterima maupun tidak. Bagaimanapun karyawan disosialisasikan, tingkat sukses yang dicapai akan tergantung pada 
kecocokan nilai-nilai yang dianut oleh karyawan baru dengan nilai-nilai organisasi dalam proses seleksi maupun pada preferensi.

\section{Komunikasi}

Effendy (2006:5) berpendapat bahwa secara pragmatis komunikasi adalah proses penyampaian suatu pesan oleh seseorang kepada orang lain untuk memberi tahu atau mengubah sikap, pendapat atau perilaku, baik langsung secara lisan maupun tak langsung melalui media. Menurut Wahyudi (1986:29) pengertian komunikasi memang sangat sederhana dan mudah dipahami, tetapi dalam pelaksanaannya sangat sulit dipahami, terlebih lagi bila yang terlibat komunikasi memiliki referensi yang berbeda, atau di dalam komunikasi berjalan satu arah misalnya media massa, tentunya untuk membentuk persamaan ini akan mengalami banyak hambatan.

\section{Pendidikan dan Pelatihan}

Malayu S.P Hasibuan (2010: 120) berpendapat Pendidikan dan pelatihan merupakan suatu proses untuk meningkatkan keahlian teoretis, konseptual dan moral pegawai tenaga kerja, tenaga kerja yang mendapatkan pendidikan dan pelatihan cenderung bekerja secara terampil jika dibandingkan dengan pegawai yang tidak memeroleh pendidikan dan pelatihan.

\section{Kinerja Karyawan}

Kinerja berasal dari pengertian performance, ada pula yang memberikan pengertian performance sebagai hasil kerja atau prestasi kerja. Namun sebenarnya kinerja mempunyai makna yang luas, bukan hanya hasil kerja, tetapi termasuk bagaimana proses pekerjaan berlangsung (Wibowo, 2007:7).

Menurut Kirom (2010: 51) Kinerja disebutkan sebagai suatu standar pekerjaan yang membandingkan tindakan-tindakan khusus dengan sekumpulan kepercayaan, kebijaksanaan, aturan, kebiasaan serta hal-hal lainnya yang tidak berwujud yang pada muara nya dapat disebut output atau hasil kerja seseorang atau suatu institusi. Kinerja merupakan suatu prestasi dalam rangka mengupayakan pencapaian sasaran dan target yang telah ditetapkan sebelumnya.

Menurut Torang (2013:74) kinerja (performance) adalah kuantitas dan atau kualitas hasil kerja individu atau sekelompok di dalam organisasi dalam melaksanakan tugas pokok dan fungsi yang berpedoman pada norma, standar operasional prosedur, kriteria dan ukuran yang telah ditetapkan atau yang berlaku dalam organisasi.Kinerja adalah hasil kerja secara kualitas dan kuantitas yang dicapai oleh seorang pegawai dalam melaksanakan tugasnya sesuai dengan tanggung jawab yang diberikan kepadanya (Mangkunegara, 2015:67).

\section{Penelitian Terdahulu}

Setyaningrum (2018) dalam penelitiannya yang berjudul Pengaruh Pelatihan dan Budaya Organisasi Terhadap Kinerja Karyawan Dengan Kepuasan Kerja Sebagai Variabel Intervening Pada PT. Asahimas Chemical Indonesia. Penelitian ini bersifat kuantitatif, Metode yang digunakan untuk mengumpulkan data adalah kuesioner. Responden dalam penelitian ini adalah karyawan pada PT. Asahimas Chemical Indonesia tepatnya karyawan yang bekerja pada departemen produksi yang berjumlah 180 orang. Metode analisis yang digunakan dalam penelitian ini adalah analisis regresi linear dan analisis jalur melalui software SPSS 21. Hasil penelitian ini menunjukkan hasil bahwa terdapat pengaruh pelatihan dan budaya organisasi terhadap kepuasan kerja secara parsial, terdapat pengaruh pelatihan dan budaya organisasi terhadap kinerja karyawan 
secara parsial, terdapat pengaruh kepuasan kerja, terdapat pengaruh pelatihan terhadap kinerja karyawan yang diintervening oleh kepuasan kerja dan terdapat pengaruh budaya organisasi terhadap kinerja karyawan yang diintervening oleh kepuasan kerja.

Riana, Hendriani, dan Efni (2017) dalam penelitiannya yang berjudul Pengaruh Pendidikan Dan Pelatihan, Remunerasi Dan Budaya Organisasi Terhadap Kepuasan Kerja Dalam Meningkatkan Kinerja Pada Dit Reskrimsus Polda Riau. Penelitian ini bertujuan untuk mengetahui Pengaruh Pendidikan dan Pelatihan, Remunerasi dan Budaya Organisasi Terhadap Kepuasan Kerja Dalam Meningkatkan Kinerja pada Dit Reskrimsus Polda Riau. Rancangan penelitian yang digunakan adalah penelitian explanatori. Populasi penelitiannya personil Dit Reskrimsus Polda Riau sebanyak 93 orang. Sampel diambil dengan teknik sensus dengan mengeluarkan Direktur Dit Reskrimsus sebagai key informan sehingga sampel yang digunakan sebanyak 92 orang. Pengumpulan data variabel menggunakan kuesioner dengan skala likert. Hasil uji hipotesis menyimpulkan: Pendidikan dan pelatihan tidak berpengaruh signifikan terhadap kinerja. remunerasi tidak berpengaruh signifikan terhadap kinerja. budaya organisasi berpengaruh signifikan terhadap kinerja. Pendidikan dan Pelatihan berpengaruh signifikan terhadap Kinerja melalui Kepuasan Kerja. Remunerasi berpengaruh signifikan terhadap Kinerja melalui Kepuasan Kerja. Budaya Organisasi berpengaruh signifikan terhadap kinerja melalui kepuasan.

Riski (2015) dalam penelitiannya yang berjudul Pengaruh Komunikasi, Komitmen Organisasi dan Motivasi Terhadap Kinerja Pegawai Inspektorat Kota Palu. Tujuan dari penelitian ini adalah: (1) untuk mengeksplorasi pengaruh komunikasi, komitmen organisasi dan motivasi terhadap kinerja resmi di Kantor Inspektorat Palu. (2) untuk menyelidiki pengaruh komunikasi terhadap kinerja pejabat di Kantor Inspektorat Palu, (3) untuk menyelidiki pengaruh komitmen organisasi terhadap kinerja pejabat di Kantor Inspektorat Palu, (4) untuk menyelidiki pengaruh motivasi pada pejabat itu. Kinerja di Kantor Inspektorat Palu, (5) untuk menyelidiki perbedaan antara kinerja pejabat pria dan wanita di Kantor Inspektorat Palu. Penelitian ini bersifat deskriptif kausal dan berfokus pada menjelaskan hubungan antar variabel. Sebanyak 48 sampel dipilih dengan metode sampel sensus, di mana semua populasi memiliki perubahan untuk dipilih sebagai sampel. Hasil penelitian menunjukkan bahwa: (1) komunikasi secara simultan, komitmen organisasi dan motivasi berpengaruh positif dan signifikan terhadap kinerja pejabat di Kantor Inspektorat Palu, (2) komunikasi berpengaruh positif dan signifikan terhadap kinerja pejabat di Kantor Inspektorat Palu, (3) komitmen organisasional berpengaruh positif dan signifikan terhadap kinerja pejabat di Kantor Inspektorat Palu, (4) motivasi berpengaruh positif dan signifikan terhadap kinerja pejabat di Kantor Inspektorat Palu, (5) tidak ada perbedaan kinerja pejabat pria dan wanita di The Kantor Inspektorat Palu. 


\section{Model Penelitian dan Hipotesa}

\section{Kerangka Konseptual}

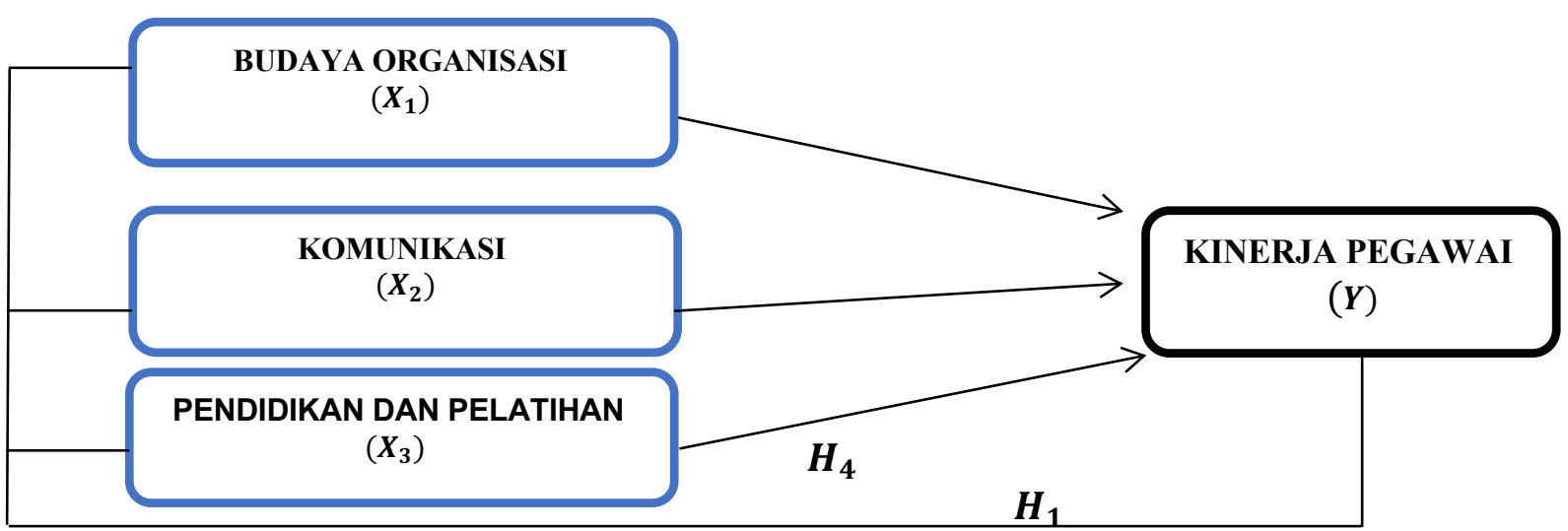

Berdasarkan model hipotesis penelitian diatas, maka hipotesis dalam penelitian ini adalah sebagai berikut:

$\boldsymbol{H}_{\mathbf{1}}$ : Budaya Organisasi , Komunikasi, Pendidikan dan Pelatihan secara simultan berpengaruh positif dan signifikan terhadap Kinerja Pegawai

$\boldsymbol{H}_{2}$ : Budaya Organisasi secara simultan dan parsial berpengaruh positif dan signifikan terhadap Kinerja Pegawai.

$\boldsymbol{H}_{3}$ : Komunikasi secara simultan dan parsial berpengaruh positif dan signifikan terhadap Kinerja Pegawai

$\boldsymbol{H}_{\mathbf{4}}$ : Pendidikan dan Pelatihan secara simultan dan parsial berpengaruh positif dan signifikan terhadap Kinerja Pegawai.

\section{METODE PENELITIAN}

\section{Populasi dan Sampel}

Jumlah populasi dalam penelitian ini berjumlah 73 pegawai negeri sipil (PNS) yang ada di Sekretariat Daerah Kabupaten Minahasa Tenggara.

\section{Teknik Pengumpulan Data}

Dalam melakukan penelitian ini, data primer yang digunakan adalah hasil kesioner dari 73 responden Pegawai Negeri Sipil (PNS) yang terkait dengan variabel budaya organisasi, komunikasi, Pendidikan dan pelatihan dan kinerja karyawan yang disebar langsung di Sekretariat Daerah Kabupaten Minahasa Tenggara.

\section{Metode Analisis Data}

Analisis data dalam penelitian ini dilakukan dengan menggunakan analisis regresi linier berganda. Pengolahan dalam penelitian ini menggunakan IBM SPSS statistics 16. 


\section{HASIL DAN PEMBAHASAN}

\section{Uji Validitas}

Dari hasil uji validitas menunjukkan bahwa semua item valid karena memiliki nilai $r$ hitung lebih besar dari r table yakni 0,227.

\section{Uji Reliabilitas}

Dari hasil uji reliabilitas menunjukkan bahwa nilai Alpha Cronbach di atas atau lebih dari 0.6, dengan demikian seluruh item variable adalah reliable.

\section{Uji Normalitas}

Berdasarkan hasil uji normalitas dengan normal probability plot, titik-titik di sekitar garis diagonal dan penyebarannya masih mengikuti garis diagonal. Hal ini berarti data telah memenuhi asumsi normalitas.

\section{Uji Heterokedastisitas}

Pada output scatterplot titik-titik menyebar diatas dan dibawah angka 0 pada sumbu $\mathrm{Y}$ dan tidak membentuk pola tertentu yang teratur, hal ini dapat disimpulkan bahwa tidak terjadi masalah heteroskedastisitas pada model regresi.

\section{Uji Multikolinearitas}

Nilai VIF dari budaya organisasi adalah 1.183, nilai VIF dari komunikasi adalah 1.137, dan nilai VIF dari pendidikan dan pelatihan adalah 1.387. Jika seluruh nilai VIF tidak lebih dari 10, maka diindikasikan tidak terjadi multikolinearitas. Karena nilai VIF dari budaya organisasi, komunikasi, pendidikan dan pelatihan tidak lebih dari 10, maka diindikasi tidak terjadi multikolinearitas. 


\section{Hasil Uji Hipotesis}

\section{Tabel Hasil Uji F}

\begin{tabular}{|c|c|c|c|c|c|c|}
\hline \multicolumn{7}{|c|}{$\mathbf{A N O V A}^{\mathbf{b}}$} \\
\hline \multicolumn{2}{|c|}{ Model } & $\begin{array}{l}\text { Sum of } \\
\text { Squares }\end{array}$ & Df & Mean Square & $\mathrm{F}$ & Sig. \\
\hline 1 & Regression & 15.239 & 3 & 5.080 & 3.002 & $.036^{\mathrm{a}}$ \\
\hline & Residual & 116.761 & 69 & 1.692 & & \\
\hline & Total & 132.000 & 72 & & & \\
\hline
\end{tabular}

a. Predictors: (Constant), PENDIDIKAN DAN PELATIHAN, KOMUNIKASI, BUDAYA ORGANISASI

b. Dependent Variable: KINERJA

Pada tabel di atas uji F menghasilkan angka F sebesar 3.002, dengan tingkat signifikansi angka probabilitas sebesar 0.036. Karena angka probabilitas $<$ dari 0.05 menunjukkan semua variabel independen (budaya organisasi, komunikasi, pendidikan dan pelatihan) secara simultan berpengaruh signifikan terhadap variabel dependen (kinerja).

Tabel Hasil Uji t

Coefficients $^{\mathrm{a}}$

\begin{tabular}{|c|c|c|c|c|c|c|}
\hline \multirow[b]{2}{*}{ Model } & \multicolumn{2}{|c|}{$\begin{array}{l}\text { Unstandardized } \\
\text { Coefficients }\end{array}$} & \multirow{2}{*}{\begin{tabular}{|c}
$\begin{array}{c}\text { Standardi } \\
\text { zed } \\
\text { Coefficie } \\
\text { nts }\end{array}$ \\
\\
Beta
\end{tabular}} & \multirow[b]{2}{*}{$\mathrm{T}$} & \multirow[b]{2}{*}{ Sig. } & \multirow[b]{2}{*}{ Ket. } \\
\hline & B & $\begin{array}{l}\text { Std. } \\
\text { Error }\end{array}$ & & & & \\
\hline $1 \quad$ (Constant) & 9.054 & 3.299 & & 2.744 & .008 & \\
\hline $\begin{array}{l}\text { BUDAYA } \\
\text { ORGANISASI }\end{array}$ & .068 & .092 & .090 & .735 & .465 & Tidak signifikan \\
\hline KOMUNIKASI & .123 & .121 & .123 & 1.020 & .311 & Tidak signifikan \\
\hline $\begin{array}{l}\text { PENDIDIKAN } \\
\text { DAN PELATIHAN }\end{array}$ & .251 & .108 & .267 & 2.313 & .024 & Signifikan \\
\hline
\end{tabular}

a. Dependent Variable:

KINERJA 
Berdasarkan tabel di atas maka dapat disusun persamaan regresi sebagai berikut:

$$
\mathrm{Y}=9.054+0.068\left(X_{1}\right)+0.123\left(X_{2}\right)+0.251\left(X_{3}\right)+\mathrm{e}
$$

Berdasarkan persamaan regresi tersebut dapat dijelaskan sebagai berikut:

a. Budaya Organisasi $\left(X_{1}\right)$

Bahwa variabel Budaya Organisasi $\left(X_{1}\right)$ menunjukkan pengaruh yang positif terhadap Kinerja $(Y)$, namun pengaruh positif Budaya Organisasi $\left(X_{1}\right)$ tersebut belum memenuhi dasar keputusan yang signifikan karena nilai probabilitas (sig) $\mathrm{t}>5 \%(0.465>0.05)$. Artinya secara parsial variabel Budaya Organisasi $\left(X_{1}\right)$ berpengaruh positif dan tidak signifikan terhadap variabel Kinerja $(Y)$. Dengan demikian hipotesa yang menyatakan terdapat pengaruh positif dan signifikan variabel Budaya Organisasi $\left(X_{1}\right)$ terhadap variabel Kinerja $(Y)$ ditolak.

b. Komunikasi $\left(X_{2}\right)$

Bahwa variabel Komunikasi $\left(X_{2}\right)$ menunjukkan pengaruh yang positif terhadap Kinerja $(Y)$, namun pengaruh positif Komunikasi $\left(X_{2}\right)$ tersebut belum memenuhi dasar keputusan yang signifikan karena nilai probabilitas $($ sig) $\mathrm{t}>5 \%(0.311>0.05)$. Artinya secara parsial variabel Komunikasi $\left(X_{2}\right)$ berpengaruh positif dan tidak signifikan terhadap variabel Kinerja $(Y)$. Dengan demikian hipotesa yang menyatakan terdapat pengaruh positif dan signifikan variabel Komunikasi $\left(X_{2}\right)$ terhadap variabel Kinerja $(Y)$ ditolak.

c. Pendidikan dan Pelatihan $\left(X_{3}\right)$

Bahwa variabel Pendidikan dan Pelatihan $\left(X_{3}\right)$ menunjukkan pengaruh yang positif terhadap Kinerja $(Y)$, dan pengaruh positif variabel Pendidikan dan Pelatihan $\left(X_{3}\right)$ tersebut memenuhi dasar keputusan yang signifikan karena nilai probabilitas (sig) $\mathrm{t}<5 \%$ $(0.024<0.05)$. Artinya secara parsial variabel Pendidikan dan Pelatihan $\left(X_{3}\right)$ berpengaruh positif dan signifikan terhadap variabel Kinerja $(Y)$. Dengan demikian hipotesa yang menyatakan terdapat pengaruh positif dan signifikan variabel Pendidikan dan Pelatihan $\left(X_{3}\right)$ terhadap variable Kinerja $(Y)$ diterima.

\section{PEMBAHASAN.}

\section{Pengaruh Budaya Organisasi $\left(X_{1}\right)$, Komunikasi $\left(X_{2}\right)$, Pendidikan dan Pelatihan $\left(X_{3}\right)$ Terhadap Kinerja Pegawai $(Y)$}

Hasil pengujian hipotesis secara simultan menunjukkan bahwa variabel Budaya Organisasi, Komunikasi, Pendidikan dan Pelatihan secara bersama-sama berpengaruh signifikan terhadap Kinerja Pegawai. Hal ini dapat dilihat pada pada tabel 5.12 angka F sebesar 3.002, dengan tingkat signifikansi angka probabilitas sebesar 0.036. Karena angka probabilitas $<$ dari 0.05 menunjukkan semua variabel independen (budaya organisasi, komunikasi, pendidikan dan pelatihan) secara simultan berpengaruh signifikan terhadap variabel dependen (kinerja).

Hal ini sangat wajar jika keseluruhan variabel tersebut mampu berpengaruh secara simultan dikarenakan penanaman nilai budaya organisasi, komunikasi yang baik, serta pengetahuan yang tinggi, merupakan faktor-faktor yang akan memberikan motivasi terbaik untuk meningkatkan kinerja pegawai. Dengan demikian hasil penelitian ini memberikan penjelasan dimana kinerja pegawai di Sekretariat Daerah Kabupaten Minahasa Tenggara dipengaruhi oleh faktor budaya organisasi, komunikasi, serta Pendidikan dan pelatihan. 
Seluruh variabel tersebut telah dibahas secara parsial dan memiliki pengaruh positif walaupun terdapat dua variabel yang tidak signifikan.

\section{Pengaruh Budaya Organisasi $\left(X_{1}\right)$ Terhadap Kinerja Pegawai $(Y)$}

Hasil Pengujian secara parsial menunjukkan bahwa variabel Budaya Organisasi $\left(\boldsymbol{X}_{\mathbf{1}}\right)$ menunjukkan pengaruh yang positif terhadap Kinerja $(Y)$, namun pengaruh positif Budaya Organisasi $\left(\boldsymbol{X}_{\mathbf{1}}\right)$ tersebut belum memenuhi dasar keputusan yang signifikan karena nilai probabilitas $(\mathrm{sig}) \mathrm{t}>5 \%(0.465>0.05)$. Artinya secara parsial variabel Budaya Organisasi $\left(X_{1}\right)$ berpengaruh positif dan tidak signifikan terhadap variabel $\operatorname{Kinerja~}(Y)$.

Dengan demikian penelitian ini tidak sejalan dengan hipotesa yang menyatakan terdapat pengaruh positif dan signifikan variabel Budaya Organisasi $\left(\boldsymbol{X}_{\mathbf{1}}\right)$ terhadap variabel Kinerja $(Y)$. Hasil penelitian ini juga tidak sejalan dengan penelitian yang dilakukan oleh Arianty (2014: 150) bahwa ada pengaruh yang signifikan antara budaya organisasi dengan kinerja karyawan, dikarenakan berbedanya lokasi dan objek serta jumlah responden dalam penelitian ini

Tidak sejalannya penelitian ini diduga karena adanya perbedaan tempat, waktu dan objek penelitian yang digunakan. Tidak berpengaruhnya budaya organisasi terhadap kinerja pegawai Sekretariat Daerah Kabupaten Minahasa Tenggara mungkin disebabkan karena nilai-nilai budaya organisai belum sepenuh nya tertanam dalam diri pegawai.

Seperti yang dikatakan oleh Robbins (Nur'Aini, 2012) Budaya Organisasi dapat memiliki pengaruh yang bermakna pada sikap dan kinerja pegawainya, ketika budaya organisasi yang dimiliki sebuah perusahaan atau institusi tersebut kuat akan mendorong munculnya sense of belonging pegawai pada organisasi, sehingga berdampak pada kinerja pegawai.

Budaya yang kuat dicirikan oleh nilai inti dari organisasi yang dianut dengan kuat, diatur dengan baik, dan dirasakan bersama secara luas. Makin banyak anggota yang menerima nilai-nilai inti maka makin kuat budaya tersebut. Dalam lingkungan dengan budaya organisasi yang kuat, pegawai merasakan adanya kesepahaman yang menjadi pengikat antar anggota dan berpengaruh secara positif pada kinerja pegawai.

Oleh karena itu budaya organisasi di Sekretariat Daerah Kabupaten Minahasa Tenggara perlu disosialisasikan, diperkuat serta diperkenalkan lagi kepada pegawai agar persepsi pegawai seiring dengan nilai-nilai organisasi. Dimana jika pegawai dapat beradaptasi dan menerima budaya organisasi maka pegawai tersebut dapat merasa lebih nyaman berada di dalam organisasi dan menunjukkan loyalitasnya serta berupaya memberikan kontribusi yang baik untuk organisasi.

\section{Pengaruh Komunikasi $\left(X_{2}\right)$ Terhadap Kinerja Pegawai $(Y)$}

Hasil Pengujian secara parsial menunjukkan bahwa variabel Komunikasi $\left(X_{2}\right)$ menunjukkan pengaruh yang positif terhadap Kinerja $(Y)$, namun pengaruh positif Komunikasi $\left(X_{2}\right)$ tersebut belum memenuhi dasar keputusan yang signifikan karena nilai probabilitas $($ sig $) \mathrm{t}>$ $5 \%(0.311>0.05)$. Artinya secara parsial variabel Komunikasi $\left(X_{2}\right)$ berpengaruh positif dan tidak signifikan terhadap variabel $\operatorname{Kinerja~}(Y)$.

Dengan demikian penelitian ini tidak sejalan dengan hipotesa yang menyatakan terdapat pengaruh positif dan signifikan variabel Komunikasi $\left(X_{2}\right)$ terhadap variabel Kinerja $(Y)$. Hasil penelitian ini juga tidak sejalan dengan penelitian yang dilakukan oleh Trijaya (2012) yang mengemukakan kompensasi, pelatihan, dan komunikasi berpengaruh signifikan terhadap kinerja karyawan dan yang menjadi variabel dominan adalah kompensasi. Hariyanti dan Primawesri 
(2011) juga mengemukakan motivasi dan komunikasi berpengaruh positif terhadap kinerja karyawan melalui komitmen organisasi, dan juga penelitian Rachmadi (2010) motivasi, partisipasi, dan komunikasi berpengaruh signifikan terhadap kinerja karyawan, dikarenakan berbedanya lokasi dan objek serta jumlah responden dalam penelitian ini

Seperti yang diketahui komunikasi sangat dibutuhkan dalam organisasi. Menurut Thayer (dalam Hardjana, 2016:129) sistem ini dibutuhkan oleh setiap organisasi untuk menjalankan fungsi-fungsi internal dan eksternal organisasi, yang berpengaruh pada kemampuan organisasi untuk mencapai tujuan dan memelihara perkembangan. Untuk organisasi yang besar, adalah penting untuk merancang sistem komunikasi yang sekaligus dapat membuat organisasi mampu menangani lingkungan, memelihara kerja fungsi internal, dan mengerti dan mampu melakukan perubahan yang dibutuhkan atau yang cocok.

Selain itu peran seorang pimpinan harus dapat membangun, memelihara sebuah komunikasi yang efektif, serta meningkatkan kinerja anggota organisasi, pemimpin harus merumuskan dan menentukan arah tujuan organisasi, dalam hal ini Sekretariat Daerah Kabupaten Minahasa Tenggara masih kurang dalam membangun komunikasi internal antara pimpinan dan pegawai, selain itu komunikasi juga diperlukan untuk menjalin hubungan antar sesama pegawai sehingga dapat saling menghormati, menghargai, dan saling membantu untuk mencapai tujuan organisasi.

\section{Pengaruh Pendidikan dan Pelatihan $\left(X_{3}\right)$ Terhadap Kinerja Pegawai $(Y)$}

Hasil Pengujian secara parsial menunjukkan bahwa variabel Pendidikan dan Pelatihan $\left(X_{3}\right)$ menunjukkan pengaruh yang positif terhadap Kinerja $(Y)$, pengaruh positif Pendidikan dan Pelatihan $\left(X_{3}\right)$ tersebut memenuhi dasar keputusan yang signifikan karena nilai probabilitas (sig) $\mathrm{t}<5 \%(0.024<0.05)$. Artinya secara parsial variabel Pendidikan dan Pelatihan $\left(X_{3}\right)$ berpengaruh positif dan signifikan terhadap variabel Kinerja $(Y)$.

Dengan demikian penelitian ini sejalan dengan hipotesa yang menyatakan terdapat pengaruh positif dan signifikan variabel Pendidikan dan Pelatihan $\left(X_{3}\right)$ terhadap variabel Kinerja $(Y)$. Hasil dari penelitian ini sejalan dengan penelitian yang dilakukan oleh Martha Monroza Siagian (2010) dalam skripsi "Pengaruh Pendidikan dan Pelatihan terhadap Kinerja Pegawai Dinas Tenaga Kerja Kota Medan" menyatakan bahwa terdapat pengaruh antara pendidikan dan pelatihan terhadap kinerja pegawai. Adapun besarnya pengaruh antara variabel $\mathrm{X}$ (Pendidikan dan Pelatihan) terhadap variabel Y (Kinerja Pegawai) adalah sebesar 31,36\%. Penelitian lain yang mendukung dilakukan oleh Flavia Da Costa Henriques (2014) dalam skripsi "Pengaruh Program Pendidikan dan Pelatihan terhadap Kinerja Pegawai (Studi Kasus Pada Instituto Nacional da administração Publica Timor Leste)" menunjukkan bahwa nilai korelasi 0,536 dengan nilai $\mathrm{t}$ hitung lebih besar dari t tabel $(3,645>1,6)$. Hasil hipoteses menunjukkan bahwa Ha diterima, artinya Pendidikan dan Pelatihan berpengaruh positif dan signifikan terhadap kinerja karyawan di Instituto Nacional da Administração Publica (INAP) Timor Leste.

Solusi yang dapat dilakukan untuk meningkatkan pendidikan dan pelatihan pegawai yaitu salah satunya dengan melaksanakan evaluasi pendidikan dan pelatihan bagi pegawai secara rutin setiap 2 kali dalam satu tahun. Evaluasi Pendidikan dan Pelatihan bertujuan mengetahui penerapan hasil pendidikan dan pelatihan oleh peserta diklat pada instansi. Selain itu pegawai harus sadar akan tanggung jawabnya. 


\section{KESIMPULAN}

Dari hasil penelitian dan pembahasan diatas, dapat ditarik kesimpulan bahwa, Hasil pengujian hipotesis secara simultan menunjukkan bahwa variabel Budaya Organisasi, Komunikasi, Pendidikan dan Pelatihan secara bersama-sama berpengaruh signifikan terhadap Kinerja Pegawai, secara parsial menunjukkan bahwa variabel Budaya Organisasi $\left(X_{1}\right)$ berpengaruh positif dan tidak signifikan terhadap variabel Kinerja $(Y)$, secara parsial menunjukkan bahwa variabel Komunikasi $\left(\boldsymbol{X}_{\mathbf{2}}\right)$ berpengaruh positif dan tidak signifikan terhadap variabel Kinerja $(Y)$, secara parsial menunjukkan bahwa variabel Pendidikan dan Pelatihan $\left(\boldsymbol{X}_{\mathbf{3}}\right)$ berpengaruh positif dan signifikan terhadap variabel Kinerja $(Y)$.

\section{SARAN}

Berdasarkan pada hasil temuan dan kesimpulan penelitian ini, dapat dikemukakan saran-saran yang menjadi rekomendasi sebagai berikut: Sekretariat Daerah Kabupaten Minahasa Tenggara perlu menanamkan kembali nilai-nilai budaya organisasi kepada para pegawai. Komunikasi antara pimpinan dan pegawai, serta sesama pegawai perlu ditingkatkan karena akan mempengaruhi atau berdampak pada kinerja pegawai didalam organisasi. Perlu adanya perencanaan peningkatan pengetahuan, kemampuan, dan keterampilan pegawai secara berkala dan berkesinambungan, sesuai dengan kebutuhan pegawai sehingga para pegawai akan dapat menguasai bidang pekerjaannya. Perlu adanya evaluasi yang dilakukan oleh instansi terhadap para pegawai yang sudah mengikuti pendidikan dan pelatihan sehingga dapat mengetahui apa yang telah didapatkan pegawai semasa diklat dan mengetahui apa yang perlu diperbaiki lagi untuk meningkatkan kinerja pegawai. Bagi akademisi atau peneliti lain selanjutnya diharapkan dapat melakukan penelitian dengan mengembangkan variabel-variabel selain budaya organisasi, komunikasi dan Pendidikan dan pelatihan. Pengembangan yang dimaksud yaitu dengan mencari variabel-variabel lain yang dapat mempengaruhi kinerja. Sehingga penelitian yang terkait dengan pengembangan SDM menjadi lebih lengkap. Hasil penelitian ini kinerja pegawai hanya bisa dijelaskan sebesar 11.5\% oleh ketiga variabel bebas

\section{DAFTAR PUSTAKA}

Alas, R., Übius, U., Lorents, P., \& Matsak, E. (2017). Corporate Social Responsibility In European And Asian Countries. Jurnal Manajemen Bisnis Dan Inovasi (JMBI) UNSRAT Vol. 4 No. 1

Ardana, I Komang. (2012). “Manajemen Sumber Daya Manusia”. Yogyakarta: Graha ilmu.

Effendy. (2006). Ilmu Komunikasi; Teori dan Praktek. Bandung: Penerbit Remaja Rosda Karya.

Hasibuan, S.P. Malayu. 2013. Manajemen Sumber Daya Manusia, Jakarta. Penerbit PT. Bumi Aksara.

Karamoy, H., \& Tulung, J. E. (2020). The Effect of Banking Risk on Indonesian Regional Development Bank. Banks and Bank Systems, 15(2), 130-137

Karamoy, H., \& Tulung, J. E. (2020). The Effect of Financial Performance and Corporate Governance To Stock Price In Non-Bank Financial Industry. Corporate Ownership \& Control, 17(2), 97-103. 
Kirom, Bahrul. (2010). Mengukur Kinerja Pelayanan dan Kepuasan Konsumen. Bandung: PRC. Pustaka Reka Cipta.

Mangkunegara, AA. Anwar Prabu, 2015, Manajemen Sumber Daya Manusia. Bandung: Perusahaan. Remaja Rosdakarya.

Mojambo, G. A., Tulung, J. E., \& Saerang, R. T. (2020). The Influence of Top Management Team (TMT) Characteristics Toward Indonesian Banks Financial Performance During the Digital Era (20142018). JMBI UNSRAT (Jurnal Ilmiah Manajemen Bisnis dan Inovasi Universitas Sam Ratulangi)., 7(1).

Riana, A., Hendriani, S., \& Efni, Y. (2017). Pengaruh Pendidikan Dan Pelatihan,

Remunerasi Dan Budaya Organisasi Terhadap Kepuasan Kerja Dalam Meningkatkan Kinerja Pada Dit Reskrimsus Polda Riau. Jurnal Psikologi, 13(2), 98-114.

Robbins, Stephen P. 2001. Perilaku Organisasi: Konsep, Kontroversi, Aplikasi, Jilid 1, Edisi 8, Prenhallindo, Jakarta.

Setyaningrum, K. (2018). Pengaruh Pelatihan Dan Budaya Organisasi Terhadap Kinerja Karyawan Dengan Kepuasan Kerja Sebagai Variabel Intervening Pada PT. Asahimas Chemical Indonesia.

Torang, S. (2013). Organisasi \& Manajemen. Bandung: Penerbit Alfabeta.

Tulung, J. E., \& Ramdani, D. (2018). Independence, size and performance of the board: An emerging market research. Corporate Ownership \& Control, 15(2-1), 201-208.

Tulung, J.E. (2017). Resource Availability and Firm's International Strategy as Key Determinants of Entry Mode Choice. Jurnal Aplikasi Manajemen, 15(1), 160-168.

Tulung, J. E., \& Ramdani, D. (2015). The Influence of Top Management Team Characteristics on BPD Performance. International Research Journal of Business Studies, 8(3), 155-166 